\title{
Pengaruh Stres Kerja Terhadap Produktivitas Kerja Karyawan Pada PT.Telkom Witel Bekasi
}

\author{
Amelia Eka Safitri ${ }^{1}$, Alini Gilang ${ }^{2}$ \\ Universitas Telkom \\ 1ªmeliaekas@student.telkomuniversity.ac.id \\ ²alinigilang55@gmail.com
}

\begin{abstract}
ABSTRAK
Penelitian ini dilakukan untuk mengetahui pengaruh stres kerja terhadap produktivitas kerja karyawan pada PT. Telkom Witel Bekasi. Tujuan dilakukannya penelitian ini adalah untuk mengetahui dan menganalisis bagaimana tingkat stres kerja pada karyawan, bagaimana produktivitas kerja karyawan dan besarnya pengaruh stres kerja terhadap produktivitas kerja karyawan yang ada di PT.Telkom Witel Bekasi. Penelitian ini menggunakan metode kuantitatif dengan jenis penelitian deskriptif-kausal. Pengambilan sampel dilakukan dengan metode probability sampling, dengan jumlah responden sebanyak 63 orang. Teknik analisis data yang digunakan adalah analisis deskriptif dan analisis regresi linear sederhana. Hasil penelitian menunjukan bahwa stres kerja berpengaruh signifikan terhadap produktivitas kerja karyawan PT.Telkom Witel Bekasi. Hal ini dibuktikan melalui hasil uji hipotesis (uji-t).
\end{abstract}

Kata Kunci: stres kerja, produktivitas kerja, sumber daya manusia

\begin{abstract}
Entering the era of globalization, business competition is getting stronger. Competition can be seen from the number of existing competitors with the same type of business. In addition, business opportunities are also increasingly open due to increasingly sophisticated technological advancements. To be able to compete in the increasingly tight business world, companies must have products or services that are superior to competitors. This can be realized if the company has quality human resources. This research was conducted to determine the effect of work stress on employee productivity at PT. Telkom Witel Bekasi. The purpose of this study was to find out and analyze how the level of work stress of employees, how the work productivity of employees and the magnitude of the influence of work stress on employee productivity at PT. Telkom Witel Bekasi. This study uses a quantitative method with a type of descriptive-causal research. Sampling is done by probability sampling method, with the number of respondents as many as 63 people. The data analysis technique used is descriptive analysis and simple linear regression analysis. The results showed that work stress had a significant effect on the work productivity of employees of PT. Telkom Witel Bekasi. This is evidenced by the results of hypothesis testing (t-test) where t-count.
\end{abstract}

Keyword: work stress, employee productivity, human resources

Naskah diterima: 18 Juli 2019, direvisi: 13 Agustus 2019, diterbitkan: 16 September 2019

ISSN: 2355-0295, e-ISSN: 2549-8932

http://ejournal.bsi.ac.id/ejurnal/index.php/ecodemica 


\section{PENDAHULUAN}

Masuknya era globalisasi saat ini, dapat diketahui kompetitor bisnis semakin banyak yang artinya persaingan bisnis semakin luas dan ketat. Dapat dilihat dari banyaknya kompetitor yang ada dengan jenis bisnis yang sejenis yang artinya persaingan semakin banyak. Didukung oleh kemajuan teknologi saat ini yang semakin canggih, hal ini membuat peluang bisnis juga semakin terbuka. Untuk bisa bersaing di dunia bisnis yang semakin ketat ini, perusahaan harus memiliki produk atau jasa yang lebih unggul dari para kompetitor. Hal ini bisa terwujud jika sumber daya manusia yang dimiliki perusahaan berkualitas.

PT. Telkom Indonesia (Persero) Tbk (Telkom) adalah Badan Usaha Milik Negara (BUMN) yang bergerak di bidang jasa teknologi informasi dan komunikasi (TIK) dan jaringan telekomunikasi di Indonesia. PT.Telkom tersebar di beberapa wilayah Indonesia, salah satunya adalah Bekasi. PT. Telkom Witel Bekasi merupakan Kantor Wilayah Usaha Telekomunikasi Bekasi yang termasuk didalam divisi Regional II Jakarta. PT. Telkom mempunyai beberapa portofolio bisnis salah satunya adalah FIXED, portofolio fixed ini memberikan layanan fixed service, meliputi fixed voice, fixed broadband, termasuk layanan Wi-Fi dan emerging wireless technology lainnya, dengan brand IndiHome

Pada penelitian ini peneliti akan membahas pengaruh stres kerja terhadap produktivitas kerja karyawan pada PT.Telkom Witel Bekasi. Peneliti menemukan fenomena pada perusahaan, dapat dilihat bahwa perusahaan menetapkan target di setiap penjualannya namun target yang ditetapkan perusahaan terlihat cukup tinggi namun perusahaan belumsepenuhnya mencapai target, hasil pencapaian target dapat dilihat pada gambar berikut:

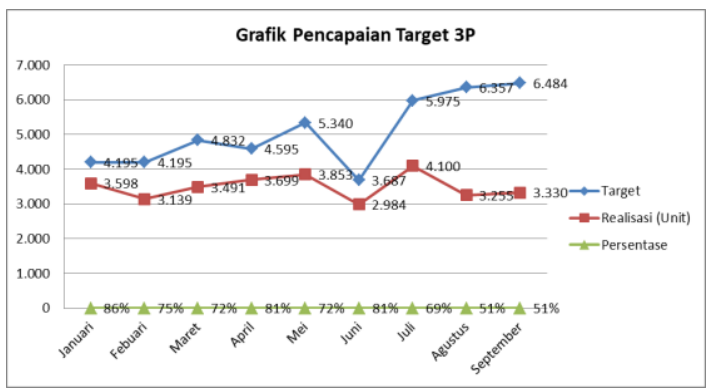

Gambar 1. Pencapaian Target Penjualan 3P

Berikut adalah grafik pencapaian target 2P:

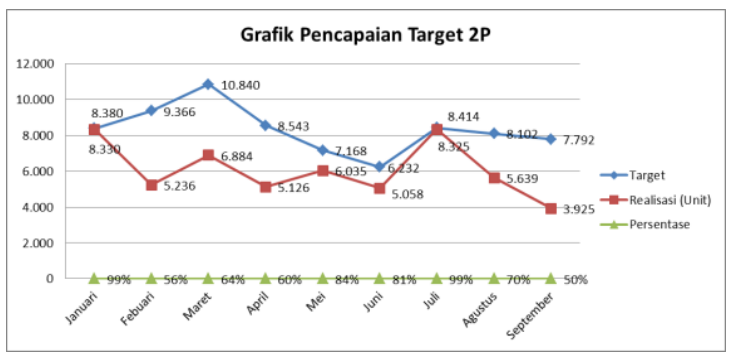

Gambar 2. Pencapaian Target Penjualan 2P

Dapat dilihat pada gambar 1.1 dan 1.2, hasilnya menunjukan bahwa pencapaian target penjualan layanan $3 \mathrm{P}$ dan $2 \mathrm{P}$ pada bulan Januari-September 2018 belum sepenuhnya mencapai target yang ditentukan oleh perusahaan. Menurut Fahmi (2016), pimpinan yang biasanya memaksa agar karyawan bekerja sesuai dengan target atau bahkan harus melebihi target, sementara kemampuan seorang karyawan sendiri tidak sesuai dengan target walaupun sebenarnya ia telah berusaha, maka ini menjadi penyebab timbulnya stres kerja.

Berdasarkan hasil wawancara penulis dengan salah satu karyawan, salah satu penyebab belum tercapainya target mungkin dikarenakan banyaknya kompetitor dengan harga yang ditawarkan lebih murah. Sehingga membuat konsumen beralih. Selain itu penulis juga melakukan wawancara kepada salah satu karyawan HR di PT.Telkom Witel Bekasi, ada beberpa faktor yang dapat mempengaruhi stres kerja karyawan di PT.Telkom Khususnya Witel Bekasi. Faktor yang paling utama adalah karyawan merasa target yang ditetapkan 
oleh perusahaan selalu meningkat, karyawan dituntut untuk bisa mencapai target atau melebihi target agar bisa mendapatkan penilaian yang baik dari perusahaan, penilaian tersebut berpengaruh untuk penaikan jabatan serta besaran gaji. Penempatan bidang atau divisi terhadap karyawan juga sangat berpengaruh, karena jika tidak sesuai dengan passion karyawan akan menimbulkan stres kerja dan produktivitas karyawan. Masalah pribadi dengan rekan kantor sedikit berpengaruh untuk karyawan, ada karyawan stres karena mendapat tekanan dari orang-orang sekitarnya. Namun ada karyawan yang menjadikan penilaian ini sebagai stres yang positif sehingga semakin produktif dalam bekerja.

Penelitian terdahulu yang berjudul Pengaruh Stres dan Motivasi terhadap Produktivitas Kerja Karyawan pada PT. Epson Batam (Cherny\&Kartikasari, 2017). Jenis penelitian yang digunakan adalah deskriptif, sampel pada penelitian sebanyak 100 orang menggunakan area sampling. Teknik pengumpulan data dalam penelitian ini melalui data primer dan sekunder. Hasil yang didapat pada penelitian tersebut bahwa, variabel stres kerja dan motivasi kerja berpengaruh positif dan signifikan secara simultan terhadap produktivitas kerja karyawan. Namun secara parsial stres kerja diketahui tidak memiliki pengaruh yang positif dan signifikan terhadap produktivitas kerja, namun variabel motivasi kerja secara parsial berpengaruh positif dan signifikan terhadap produktivitas kerja.

Pada penelitian yang telah dilakukan sebelumnya yang berjudul Hubungan Antara Stres Kerja dengan Produktivitas Kerja Karyawan (Saputri, 2012). Penelitian ini dilakukan pada CV. Mediatama Surakarta. Teknik penelitian yang digunakan adalah korelasi product moment, sampel pada penelitian sebanyak 58 orang dengan pengambilan sampel studi populasi. Teknik pengumpulan data dilakukan melalui teknik korelasi data stres kerja dan produktivitas kerja. Hasil yang di dapat dari penelitian Saputri yaitu, terdapat pengaruh negatif signifikan antara stres kerja dengan produktivitas kerja, yang artinya jika stres kerja semakin tinggi maka tingkat produktivitas kerjanya akan semakin menurun.

Berdasarkan fenomena diatas, penulis melihat adanya peluang untuk meneliti lebih jauh tentang kondisi internal karyawan PT.Telkom Bekasi terhadap stres kerja dan produktivitas kerja para karyawan. Judul pada penelitian ini adalah: "Pengaruh Stres Kerja Terhadap Produktivitas Kerja Karyawan PT.Telkom Witel Bekasi”.

Berdasarkan uraian pada latar belakang diatas, maka rumusan masalah pada penelitian ini adalah:

1) Bagaimana tingkat stres kerja karyawan PT.Telkom Witel Bekasi?

2) Bagaimana produktivitas kerja karyawan PT.Telkom Witel Bekasi?

3) Bagaimana pengaruh tingkat stres kerja terhadap produktivitas kerja karyawan PT.Telkom Witel Bekasi?

\section{KAJIAN LITERATUR}

\section{Manajemen Sumber Daya Manusia}

Hamali (2016) Manajemen SDM difungsikan perushaan untuk membentuk kultur suatu organisasi/perusahaan yang layak, serta memasukan berbagai program yang dapat menggambarkan, mendukung nilai-nilai pokok dari perusahaan tersebut dan memastikan keberhasilan suatu perusahaan.

\section{Stres}

Stres menurut Fahmi (2016) adalah suatu keadaan diluar batas kemampuan seseorang yang dianggap menekan diri dan jiwa seseorang, sehingga jika hal tersebut terus dibiarkan tanpa ada solusi maka akan berdampak pada kesehatan. Stres ditimbulkan oleh berbagai macam peristiwa yang dialami seseorang umumnya peristiwa itu terjadi di luar kemampuannya.

\section{Stres Kerja}

Dalam Priansa (2017) stres kerja adalah ketidakseimbangan antara kemampuan fisik 
dan psikis dalam mengemban pekerjaan yang diberikan oleh organisasi bisnis sehingga mempengaruhi berbagai aspek yang berkenaan dengan aspek emosi, berpikir, bertindak dan lainnya dari individu karyawan. Ketidak-seimbangan tersebut akan memberikan dampak yang beranekaragam bagi setiap individu.

Dalam Hamali (2016) Stres di tempat kerja adalah sebuah masalah yang makin bertambah bagi para pekerja, majikan dan masyarakat. Stres diakibatkan oleh kondisi kelebihan kerja, ketidaknyamanan kerja, tingkat kepuasan kerja yang rendah dan ketiadaan otonomi. Stres di tempat kerja telah terbukti berpengaruh negatif terhadap produktivitas dan keuntungan di tempat kerja.

Pranoto, et al (2016), Stres kerja bisa dipahami sebagai keadaan dimana seseorang menghadapi tugas atau pekerjaan yang tidak bisa atau belum bisa dijangkau oleh kemampuannya.

\section{Dimensi Stres Kerja}

Menurut Robbins dalam Priansa (2017) menyatakan tiga faktor yang dapat menjadi penyebab stres kerja, yaitu:

\section{1) Faktor Lingkungan}

a. Ketidakpastian Ekonomi

Ketika sedang terjadi penurunan ekonomi, maka seseorang akan cenderung semakin mencemaskan keamanan keuangan mereka.

b. Ketidakpastian Politik

Dapat terjadi karena disebabkan oleh perubahan sistem politik maupun rejim penguasa sehingga menyebabkan kondisi politik menjadi tidak stabil.

c. Ketidakpastian Teknologi

Berbagai inovasi yang baru akan membuat keterampilan dan pengalaman seorang karyawan menjadi tertinggal dalam periode waktu yang sangat singkat.

2) Faktor Organisasi a. Tuntutan tugas

Merupakan faktor yang dapat

dihubungkan pada

pekerjaan seseorang. Faktor ini

menyangkut bentuk pekerjaan individu, kondisi kerja dan tata letak kerja fisik. Tuntutan tugas dapat membuat seseorang tertekan bila kecepatannya dirasa berlebihan. Semakin banyak ketergantungan antar tugas pribadi dengan tugas orang lain keadaan stres akan semakin potensial.

b. Tuntutan Peran

Berhubungan dengan tekanan yang diberikan kepada seseorang sebagai salah satu fungsi dari peran tertentu yang diterapkan dalam organisasi tersebut. Ambiguitas peran diciptakan bila harapan peran dipahami dengan jelas dan karyawan tidak memiliki kepastian mengenai apa yang harus dikerjakan.

c. Tuntutan Hubungan Antarpribadi Merupakan tekanan yang di sebabkan oleh karyawan yang lain. Dukungan sosial yang kurang dari rekan-rekan kerja dan hubungan antarpribadi yang kurang baik dapat menjadi penyebab timbulnya stres yang cukup besar.

3) Faktor Individu

a. Masalah keluarga menunjukan bahwa seorang menganggap hubungan pribadinya dengan keluarga sangat berharga.

b. Masalah ekonomi yang di sebabkan oleh individu salah satunya adalah masalah keuangan merupakan suatu kesulitan pribadi yang bisa menimbulkan stres bagi karyawan.

c. Kepribadian yang berasal dari sifat yang dimiliki individu itu sendiri.

\section{Produktivitas Kerja}

Menurut Sutrisno (2016) Produktivitas diartikan sebagai hubungan antara keluaran (produk atau jasa) dengan 
masukan (karyawan, sumberdaya atau bahan baku, dan uang).

Menurut Sedarmayanti (2017) Produktivitas secara umum dikatakan perbandingan antara hasil yang dapat dicapai dengan keseluruhan daya atau faktor produksi yang dipergunakan. Atau jumlah barang/jasa yang dapat dihasilkan oleh seorang/kelompok, orang/pegawai dalam periode waktu tertentu.

Usia dapat mempengaruhi produktivitas kerja usia yang masih produktif biasanya mempunyai tingkat produktivitas yang tinggi dibandingkan dengan tenaga kerja yang sudah berusia tua sehingga fisik yang dimiliki menjadi lemah dan terbatas. (Aprilyanti,2017)

\section{Dimensi Produktivitas}

Menurut Agus dalam Nurjaman (2014) bahwa terdapat lima dimensi yang digunakan untuk pengukuran produktivitas kerja sebagai berikut:

a. Kualitas Pekerjaan

Kualitas pekerjaan menghasilkan mutu yang dihasilkan. Menurut Sinamora dalam Nurjaman (2014) kualitas pekerjaan adalah hasil yang berkaitan dengan dengan mutu dari suatu hasil produk atau jasa karyawan, dalam hal ini merupakan suatu kemampuan untuk menyelesaikan pekerjaan secara teknis dengan perbandingan standar yang telah ditetapkan perusahaan.

b. Kuantitas Pekerjaan

Pencapaian target termasuk kedalam kuantitas pekerjaan atau hasil kerja yang sesuai dengan rencana organisasi. Ukuran kuantitas pekerjaan harus seimbang dengan kuantitas karyawan sehingga dengan adanya keseimbangan tersebut akan membuat tenaga kerja yang produktif agar dapat meningkatkan produktivitas kerja dalam organisasi tersebut.

c. Ketepatan Waktu

Ketepatan waktu menyangkut pada seorang pegawai harus memandang waktu sebagai sumber daya yang harus di pergunakan dengan sebaikbaiknya dalam melaksanakan tugasnya.

d. Semangat Kerja

Semangat kerja menurut Moekijat dalam Nurjaman (2014) menyatakan bahwa semangat kerja mendeskripsikan perasaan yang berhubungan dengan jiwa, kegembiraan, semangat dalam kelompok dan kegiatan.

e. Disiplin Kerja

Berhubungan pada pimpinan atau pegawai yang tepat pada waktu yang telah ditentukan untu datang dan pulang kantor, melakukan tugas dengan penuh semangat dan mematuhi semua peraturan sehingga menghasilkan pekererjaan yang memuaskan baik itu kuantitas maupun kualitas.

\section{Hubungan Stres Kerja dengan Produktivitas Kerja}

Robbins\&Judge dalam Harrisma\&Witjaksono (2013) stres kerja pada tingkat tertentu akan membuat tubuh untuk dapat bereaksi lebih. Karyawan atau individu akan menjadi sering melakukan tugas mereka dengan lebih baik, lebih intensif atau lebih cepat. Stres kerja dengan kata lain pada taraf tertentu dapat meningkatkan produktivitas karyawan namun bila dibiarkan berlarut-larut akan menurunkan tingkat produktivitas kerja.

Menurut Faliza dalam Andriani (2017) menyatakan bahwa salah satu alasan stres perlu dipahami karena stres berhubungan erat dengan produktivitas. Karyawan yang mengalami stres kerja tidak dapat bekerja secara optimal sehingga akan memberi dampak yang negatif pada hasil kerjanya atau dengan kata lain pegawai tidak dapat mengoptimalkan hasil kerjanya. 


\section{Kerangka Pemikiran}

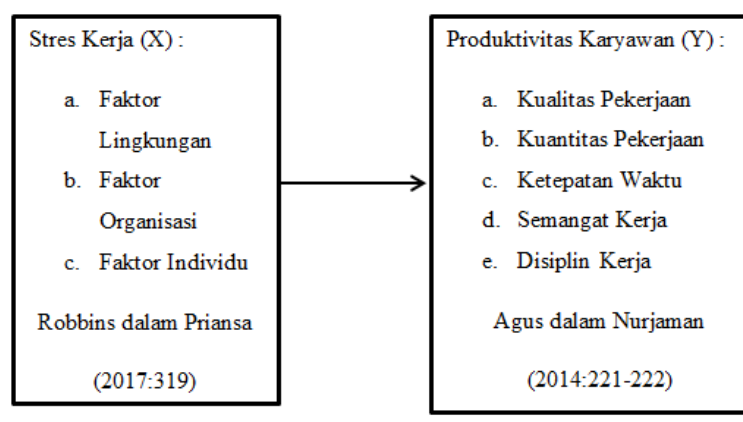

Gambar 3. Kerangka Pemikiran

\section{METODE PENELITIAN}

Penelitian ini menggunakan metode kuantitatif dengan jenis penelitian deskriptif dan kausal. Lokasi penelitian yaitu PT.Telkom Witel Bekasi. Teknik yang digunakan untuk pengumpulan data menggunakan data primer dan data sekunder. Teknik analisis data menggunakan deskriptif, Method of successive interval (MSI) dan analisis regresi linear sederhana. Terdapat dua variabel yang digunakan dalam penelitian ini, yaitu: (1) stres kerja (X) sebagai variabel bebas atau independent, (2) produktivitas kerja (Y) sebagai variabel terikat atau dependent. Populasi pada penelitian ini adalah karyawan PT.Telkom Witel Bekasi berjumlah 167 orang. Pengambilan sampel pada penelitian ini menggunakan probability sampling. Untuk menentukan sampel peneliti menggunakan rumus slovin, sehingga dalam penelitian ini diambil sampel sebanyak 63 responden. Penelitian ini dilakukan selama empat bulan dimulai sejak bulan Oktober, November, Desember 2018 dan berakhir pada bulan Januari 2019.

\section{PEMBAHASAN}

\section{Uji Validitas dan Reliabilitas}

Uuji validitas menunjukan sejauh mana suatu alat pengukur dapat mengukur apa yang ingin diukur, sehingga dapat dikatakan jika alat pengukur validitas semakin tinggi, maka alat pengukuran tersebut semakin dapat menunjukan apa yang harus diukur. (Sekaran\&Bougie dalam Indrawati (2015))

Uji validitas sebagai pengukuran kuesioner menggunakan teknik korelasi product moment. Untuk uji reliabilitas menggunakan Cronbach's Alpha. Kedua uji tersebut dilakukan dengan menggunakan bantuan software SPSS versi 21 for windows. Hasilnya menunjukan bahwa instrumen pada penelitian ini sudah valid dan reliabel. Karena pada setiap item pernyataan nilai yang dimiliki yakni $R_{\text {hitung }}$ lebih besar dari $\mathrm{R}_{\text {tabel }}(0,361)$. Hasil tersebut menunjukan bahwa semua butir pernyataan pada variabel stres kerja dan produktivitas kerja dinyatakan sudah valid dan layak untuk digunakan sebagai alat ukur penelitian. Pada uji reliabilitas yang dilakukan pada semua item pernyataan nilai koefisien lebih besar dari 0,60 maka item pernyataan pada penelitian dinyatakan reliabel (handal/konsisten). Salah satu ukuran reliabilitas internal consistency adalah melihat koefisien alpha cronbach, dimana jika $\alpha=\geq 0,6$ menunjukan instrumen tersebut dinyatakan reliabel, koefisien alpha cronbach dihitung dengan bantuan software SPSS. (Echdar, 2017)

\section{Hasil Analisis Deskriptif}

Statistik deskriptif adalah statistik yang berfungsi untuk mendeskriptifkan atau memberi gambaran pada objek yang akan diteliti melalui data populasi atau sampel, tidak melakukan analisis dan membuat kesimpulan yang berlaku untuk umum. (Sugiyono, 2015)

Analisis deskriptif digunakan untuk mengetahui gambaran dari 63 responden mengenai variabel penelitian yaitu variabel stres kerja dan variabel produktivitas kerja pada PT.Telkom Witel Bekasi, hasil yang didapat adalah sebagai berikut:

\section{Tabel 1. Hasil Analisis Deskriptif Variabel Stres Kerja}

\begin{tabular}{ccc}
\hline No & Dimensi & Skor Total \\
\hline \multirow{2}{*}{1} & Faktor Stres Lingkungan & 211 \\
\cline { 3 - 3 } & & $66,9 \%$ \\
\hline
\end{tabular}




\begin{tabular}{ccc}
\hline $\mathbf{2}$ & Faktor Stres Organisasi & 194 \\
\cline { 3 - 3 } & & $61,5 \%$ \\
\hline \multirow{3}{*}{} & Faktor Stres Individu & 186 \\
\cline { 3 - 3 } & & $58,9 \%$ \\
\hline \multirow{2}{*}{ Rata-Rata Stres Keja } & $\mathbf{1 4 7}$ \\
\cline { 3 - 3 } & & $\mathbf{6 2 , 4 \%}$ \\
\hline
\end{tabular}

Sumber: hasil olahan data penulis

Dapat dilihat pada tabel 1 stres kerja karyawan pada PT.Telkom Witel Bekasi memiliki presentase sebesar 62,5\%, presentase tersebut termasuk ke dalam kategori cukup tinggi. Stres didominasi oleh faktor lingkungan sebesar $66,9 \%$ yang memiliki arti bahwa faktor lingkungan merupakan salah satu penyebab timbulnya stres pada karyawan. Menurut Robbin dalam Badeni (2013) faktor lingkungan merupakan salah satu penyebab timbulnya stres pada kayrawan. Selain variabel stres kerja berikut adalah hasil analisis deskriptif variabel produktivitas kerja:

\section{Tabel 2. Hasil Anlisis Deskriptif Varibel Produktivitas Kerja}

\begin{tabular}{ccc}
\hline No & Dimensi & Skor Total \\
\hline $\mathbf{1}$ & Kualitas Pekerjaan & 267 \\
\cline { 3 - 3 } & & $84,6 \%$ \\
\hline $\mathbf{2}$ & Kuantitas Pekerjaan & 257 \\
\cline { 3 - 3 } & & $81,4 \%$ \\
\hline $\mathbf{3}$ & Ketepatan Waktu & 262 \\
\cline { 3 - 3 } & & $83,2 \%$ \\
\hline $\mathbf{4}$ & Semangat Kerja & 261 \\
\cline { 3 - 3 } & & $82,9 \%$ \\
\hline $\mathbf{5}$ & Disiplin Kerja & 261 \\
\cline { 3 - 3 } Rata-Rata Produktivitas \\
Kerja
\end{tabular}

Sumber: hasil olahan data penulis

Dapat dilihat pada tabel diatas bahwa produktivitas karyawan PT.Telkom Witel Bekasi secara keseluruhan termasuk dalam kategori baik. Skor terkecil terdapat pada dimensi kuantitas pekerjaan dengan presentase $81,4 \%$. Pencapaian target merupakan salah satu yang disebut kuantitas pekerjaan, hasil kerja yang sesuai dengan rencana organisasi. Rasio kuantitas pekerjaan harus seimbang dengan kuantitas pegawai sehingga dengan adanya keseimbangan tersebut akan membuat tenaga kerja yang produktif dalam meningkatkan produktivitas kerja pada organisasi tersebut (Agus dalam Nurjaman, 2014).

\section{Uji Asumsi Klasik}

Hasil uji normalitas menunjukan terdapat nilai signifikan yang berada di atas 0,05 dapat diartikan bahwa model regresi tersebut berdistribusi normal. Uji normalitas kolmogorov-smirnov diperoleh nilai probabilitas Asymp. Sig. (2-tailed) sebesar 0,187 . Niai tersebut lebih besar dari 0,05 dapat dikatakan bahwa data model regresi sudah berdistribusi normal. Uji heteroskedastitas menunjukan titik-titik menyebar secara acak dan tidak membentuk pola tertentu atau menyebar diatas dan dibawah angka nol pada sumbu Y. Sehingga dapat disimpulkan bahwa tidak terjadi heteroskedastitas.

\section{Analisis Regresi Linear Sederhana}

Menurut Indrawan \& Yaniawati (2014:170) analisis regresi linier sederhana merupakan hubungan secara linear antara variabel independen $(\mathrm{X})$ dengan variabel dependen (Y). Analisis ini digunakan untuk mengetahui hubungan antara variabel independen dengan variabel dependen, apakah arah hubungan positif atau negatif dan dilakukan untuk memprediksi nilai dari variabel dependen apabila nilai variabel independen mengalami kenaikan atau penurunan. Berikut adalah persamaan regresi linear sederhana pada penelitian ini:

Tabel 3. Analisis Regresi Linear Sederhana

\begin{tabular}{|c|c|c|c|c|c|c|}
\hline \multicolumn{7}{|c|}{ Coefficients $^{a}$} \\
\hline \multirow[b]{2}{*}{ Model } & & \multicolumn{2}{|c|}{$\begin{array}{l}\text { Unstandardized } \\
\text { Coefficients }\end{array}$} & \multirow{2}{*}{$\begin{array}{c}\begin{array}{c}\text { Standardized } \\
\text { Coefficients }\end{array} \\
\text { Beta }\end{array}$} & \multirow[b]{2}{*}{$t$} & \multirow[b]{2}{*}{ Sig. } \\
\hline & & $B$ & Std. Error & & & \\
\hline & (Constant) & 5,296 & .275 & & 19,290 &, 000 \\
\hline & Stres Kerja $(X)$ &,- 769 & .092 & -.729 & $-8,320$ & .000 \\
\hline
\end{tabular}

Sumber: hasil pengolahan data SPSS 21, 2019 
Berdasarkan hasil output SPSS pada tabel 4.2, diperoleh persamaan regresi linear sederhana sebagai berikut:

$$
Y=5,296-0,769
$$

Dari hasil persamaan regresi tersebut dapat disimpulkan nilai constant $(5,296)$, memiliki arti bahwa jika variabel bebas bernilai 0 dan tidak ada perubahan, maka produktivitas kerja karyawan akan bernilai sebesar 5,296. Sedangkan untuk nilai stres kerja sebesar (0,769), memiliki arti bahwa jika stres kerja mengalami peningkatan maka produktivitas kerja karyawan diprediksikan akan mengalami penerunan sebesar $-0,769$.

\section{Uji Hipotesis (uji-t)}

Kriteria uji hipotesis adalah sebagai berikut:

$$
\begin{array}{rrr}
\mathrm{H}_{0}: \beta_{1}=0 & \text { Stres kerja tidak berpengaruh } \\
& \text { secara rignifikan } \\
& \text { terhadap produktivitas } \\
& \text { kerja karyawan di PT. } \\
& \text { Telkom Witel Bekasi } \\
\mathrm{H}_{1}: \beta_{1} \neq 0 & \begin{array}{l}
\text { Stres kerja berpengaruh } \\
\text { secara }
\end{array} \\
& \text { terhadap produktivitan } \\
& \text { kerja karyawan di PT. } \\
& \text { Telkom Witel Bekasi }
\end{array}
$$

Dapat diketahui dari taber 3 diatas, bahwa nilai -t-hitung sebesar -8,320 lebih kecil dari -t-tabel -2,000 sehingga $\mathrm{H}_{0}$ ditolak dan $\mathrm{H} 1$ diterima, yang artinya terdapat pengaruh yang signifikan antara stres kerja dan produktivitas kerja pada PT.Telkom Witel Bekasi.

\section{Koefisien Determinasi}

Menurut Sugiyono (2013) koefisien determinasi dalam penelitian digunakan untuk mengetahui seberapa besar tingkat.pengaruh variabel independen terhadap variabel dependen. Jika koefisien determinasi semakin kecil (mendekati angka $0)$ berarti variabel bebas (X) tidak berpengaruh pada variabel terikat (Y). Dan sebaliknya jika semakin besar koefisien determinasi (mendekati angka 1), dapat dikatakan bahwa variabel bebas (X) memiliki pengaruh atau berpengaruh terhadap variabel terikat (Y). Pada penelitian ini hasil koefisien determinasi adalah sebagai berikut:

\section{Tabel 4. Koefisien Determinasi}

Model Summary
\begin{tabular}{|l|l|r|r|r|}
\hline Model & R & R Square & $\begin{array}{c}\text { Adjusted R } \\
\text { Square }\end{array}$ & $\begin{array}{c}\text { Std. Error of } \\
\text { the Estimate }\end{array}$ \\
\hline 1 &, $729^{\text {a }}$ &, 532 &, 524 &, 412698 \\
\hline
\end{tabular}
a. Predictors: (Constant), Stres Kerja $(X)$
b. Dependent Variable: Produktivitas Kerja $(Y)$

Sumber: hasil pengolahan data SPSS 21, 2019

Dapat dilihat pada tabel 4.3 diatas, bahwa nilai koefisien determinasi atau $\left(\mathrm{R}^{2}\right)$ sebesar 0,531 . Maka jika dihitung dengan rumus koefisien determinasi hasilnya adalah sebagai berikut: $\mathrm{Kd}=0,729^{2} \times 100 \%=$ $53,2 \%$. Angka tersebut menunjukan bahwa stres kerja memiliki pengaruh terhadap produktivitas kerja sebesar $53,2 \%$ dan sisanya $46,8 \%$ di pengaruhi oleh variabel lain yang tidak diteliti.

\section{Pembahasan}

Berdasarkan penelitian dari analisis deskriptif, tanggapan dari responden mengenai stres kerja pada PT.Telkom Witel Bekasi pada dimensi Lingkungan mendapatkan skor rata-rata sebesar $66,9 \%$, dimensi Organisasi mendapatkan skor ratarata sebesar $61,5 \%$ dan dimensi Individu sebesar 58,9\%. Secara keseluruhan jika dimasukan ke dalam garis kontinum variabel stres kerja berada dalam kategori cukup tinggi, memiliki arti bahwa karyawan PT.Telkom Witel Bekasi merasakan stres yang cukup tinggi. Dari 16 pernyataan yang diajukan pada variabel stres kerja, dimensi lingkungan mendapatkan skor tertinggi sebesar $66,9 \%$ hal ini menunjukan bahwa stres kerja pada karyawan PT.Telkom Witel bekasi didominasi oleh faktor lingkungan. suatu organisasi perlu menekankan dampak stres kerja pada produktivitas kerja karyawan, artinya adalah karyawan yang mengalami stres tidak boleh mempengaruhi hasil kerja sehingga target produktivitas dapat terus dicapai. Jika stres yang dialami tidak terselesaikan akan sangat berpotensi mengganggu produktivitas organisasi yang 
lebih besar, seperti terjadinya kekacauan dalam oprasional bekerja karyawan, kenormalan aktivitas kerja terganggu, serta terjadi penurunan tingkat produktivitas, peurunkan pemasukan dan keuntungan pada perusahaan (Fahmi, 2013).

Berdasarkan penelitian dari analisis deskriptif, tanggapan responden mengenai produktivitas kerja pada PT.Telkom Witel Bekasi dimensi kualitas pekerjaan mendapatkan skor rata-rata sebesar 84,6\%, dimensi kuantitas pekerjaan mendapatkan skor rata-rata sebesar $81,4 \%$, dimensi ketepatan waktu mendapatkan skor rata-rata sebesar $83,2 \%$, dimensi semangat kerja mendapatkan skor rata-rata $82,9 \%$ dan dimensi disiplin kerja mendapatkan skor rata-rata sebesar $82,9 \%$. Jika dimasukan kedalam garis kontinum variabel produktivitas berada pada kategori baik. Yang artinya produktivitas karyawan suda baik, namun pada dimensi kuantitas pekerjaan mendapat skor terendah yaitu sebesar $81,4 \%$ yang artinya kuantitas pekerjaan karyawan berada dalam kategori baik namun masih di bawah dimensi lain seperti kualitas pekerjaan, ketepatan waktu, semangat kerja dan juga dimensi disiplin kerja. Purnawati (2014), stres kerja berpengaruh negatif dan signifikan terhadap poduktivitas karyawan karena jika karyawan mengalami stres akan menyebabkan penurunan produktivitas kerjanya.

Berdasarkan hasil uji-t menunjukan hasil stres kerja memberikan pengaruh signifikan terhadap produktivitas kerja karyawan PT.Telkom Witel Bekasi. Hal ini dapat diketahui dengan melihat nilai -t-hitung (8,320) lebih kecil dari -t-tabel $(-2,048)$, maka $\mathrm{H}_{0}$ ditolak dan $\mathrm{H}_{1}$ diterima. Dapat diartikan bahwa stres kerja mempunyai pengaruh teradap produktivitas kerja sebesar $53,2 \%$ dan sisanya 46,8\% merupakan pengaruh variabel lain yang tidak diteliti. Yang artinya semakin tinggi stres kerja maka akan menimbulkan penurunan produktivitas kerjanya.

\section{PENUTUP}

Berdasarkan hasil penelitian yang dilakukan dan pembahasan yang telah dijabarkan sebelumnya mengenai pengaruh stres kerja terhadap produktivitas kerja karyawan pada PT.Telkom Witel Bekasi, dalam penelitian ini terdapat kesimpulan yang diharapkan mampu menjawab rumusan masalah yang ada, berikut adalah kesimpulannya:

Pertama, berdasarkan hasil analisis deskriptif tingkat stres kerja karyawan secara keseluruhan pada saat ini termasuk dalam kategori cukup tinggi. Stres kerja didominasi oleh faktor lingkungaan.

Kedua, berdasarkan hasil analisis deskriptif produktivitas kerja karyawan secara keseluruhan pada saat ini termasuk dalam kategori baik. Dapat diartikan karyawan PT.Telkom Witel bekasi memiliki produktivitas yang baik.

Ketiga, setelah dilakukan penelitian stres kerja memiliki pengaruh signifikan terhadap produktivitas kerja karyawan yang dibuktikan melalui uji hipotesis statistik. Berdasarkan dari hasil uji koefisien determinasi yang sudah dilakukan sebelumnya, variabel stres kerja diketahui memiliki pengaruh terhadap variabel produktivitas kerja karyawan sebesar 53,2\%.

\section{REFERENSI}

Andriani, A.A. (2017). Hubungan Stres Kerja Terhadap Produktivitas Kerja Pegawai Di Kantor Dinas Kebersihan dan Pertamanan Kota Samarinda. Jurnal Administrasi Negara, 1 (5), 5559. Ejournal, https://ejournal.an.fisipunmul.ac.id/site/?p=2384.

Aprilyanti, S. (2017). Pengaruh Usia Dan Masa Kerja Terhadap Produktivitas Kerja (Studi Kasus PT. OASIS Water International Cabang Palembang. Jurnal Sistem dan Manajemen Industri, 1 (2). Ejournal, https://www.researchgate.net/public ation/322922558_Pengaruh_Usia_d an_Masa_Kerja_Terhadap_Produkt ivitas_Kerja_Studi_Kasus_PT_OA 
SIS_Water_International_Cabang_ Palembang.

Cherny, K.B. \& Kartikasari, D. (2017). Pengaruh Stres dan Motivasi terhadap Produktivitas Kerja Karyawan pada PT. Epson Batam. Jurnal Akuntansi, Ekonomi dan Manajemen Bisnis. 5 (2), http://p2m.polibatam.ac.id/wpcontent/uploads/2018/02/306-1331185-1-10-20170727.pdf.

Echdar, Saban. (2017). Metode Penelitian Manajemen dan Bisnis. Bogor: Ghalia Indonesia.

Fahmi, Irham. (2013). Perilaku Organisasi Teori, Aplikasi, dan kasus.

Bandung: Alfabeta.

Fahmi, Irham. (2016). Manajemen Sumber Daya Manusia, Teori dan Aplikasi. Bandung: Alfabeta.

Hamali, Y.A. (2016). Pemahaman Manajaemen Sumber Daya Manusia. Bandung: CAPS.

Harrisma, O.W.\& Witjaksono, A.D. (2013). Pengaruh Stres Kerja Terhadap Produktivitas Kerja Melalui Kepuasan Kerja. Jurnal Ilmu Manajemen, 1 (2),

653, https://jurnalmahasiswa.unesa .ac.id/index.php/jim/article/downlo $\mathrm{ad} / 3049 / 5843$.

Indrawan,R. \& Yaniawati,P.R. (2014). Metodelogi Penelitian: Kuantitatif, Kualitatif, dan Campuran untuk Manajemen, Pembangunan dan Pendidikan. Bandung: PT.Refika Aditama.

Indrawati. (2015). Metode Penelitian Manajemen dan Bisnis: Konvergensi Teknologi Komunikasi dan Informatika. Bandung: Refika Aditama.

Nurjaman, K. (2014). Nur Bandung: Pustaka Setia.
Pranoto,E. Haryono,T.A.\& Warso,M.M. (2016). Pengaruh Rekrutment, Stres Kerja, dan Pemberian insentif Terhadap Produktivitas Kerja dengan Komitmen Organisasi sebagai Variabel Intervening pada PT. Ungaran Sari Garment Unit III Congol Karangjati. Journal of Management, 2 (8), https://jurnal.unpand.ac.id/index.p $\mathrm{hp} / \mathrm{MS} /$ article/view/480/466.

Priansa, D.J. (2017). Perilaku Organisasi Bisnis. Bandung: Alfabeta.

Purnawati,R.W. (2014). Pengaruh Stres Kerja terhadap Produktivitas Kerja Pegawai pada Bagian Dinas Pendapatan, Pengelolaan keuangan dan Aset Daerah (DPPKAD) Pemerintah Kota Sukabumi. Skripsi. Bandung: UPI.

Saputri, N.E. (2012). Hubungan Antara Stres Kerja dengan Produktivitas Kerja Karyawan. Naskah Publikasi. Surakarta.

Sedarmayanti. (2017). Perencanaan dan Pengembangan Sumber Daya Manusia. Bandung: Refika Aditama.

Sugiyono. (2013). Metode Penelitian Manajemen: Pendekatan Kuantitatif, Kualitatif, Kombinasi, Penelitian Tindakan dan Penelitian Evaluasi. Bandung: Alfabeta

Sugiyono. (2015). Metode Penelitian Kuantitatif, Kualitatif dan R\&D. Bandung: Alfabeta.

Sutrisno, Edy. (2016). Manajemen Sumber Daya Manusia. Jakarta: Kencana Prenada Media Group. 


\section{BIODATA PENULIS}

Amelia Eka Safitri. Lahir di Bandung, 20 September 1997. Penulis menyelesaikan pendidikan S1 di Universitas Telkom Bandung konsentrasi Ilmu

Administrasi Bisnis pada tahun 2019. 